\title{
The Past in the Present: What our Ancestors Taught us about Surviving Pandemics
}

\author{
Gabriel R. Valle ${ }^{1}$ (iD \\ Accepted: 7 April 2021 / Published online: 17 April 2021 \\ (C) The Author(s), under exclusive licence to Springer Nature Switzerland AG 2021
}

\begin{abstract}
Amidst the recent threat of COVID-19, home gardens have surged in popularity as seed companies and nurseries find it challenging to keep their supplies fully stocked. The victory garden movement that emerged during WWII has today re-emerged as COVID victory gardens. Yet, the global changes and cognitive shifts associated with COVID-19 have differential impacts. The narrative of COVID victory gardens depoliticizes urban agriculture. It is blind to its long history in marginalized, oppressed, and displaced communities where home gardens have always been part of a struggle for identity, autonomy, and self- and communal-determination. I argue the blindness embedded in the narrative of COVID victory gardens violates our "food-related obligations," which are our responsibilities to ourselves, our food, and each other. Silencing how communities of color have historically grown food in pursuit of dignity disregards how home gardens in communities of color are not merely a reactionary response to crisis but part of a historical legacy whereby people of color have grown food for generations to create and recreate sustainable ways of living that validate their cultures, knowledges, and ways of being.
\end{abstract}

Keywords COVID-19 $\cdot$ Victory gardens $\cdot$ Home gardens $\cdot$ Narrative $\cdot$ Latinx

\section{Introduction}

"Gardening is nothing new," an urban home gardener told me in the Fall of 2016. "It's ancient," he said, referring to the resurgence of urban gardening in cities across the United States and how Mexican-origin peoples have cultivated home gardens for various reasons. He showed me several different corps he grows to support him and his family. Walking through his garden, he showed me more common crops, like kale, that have entered the urban agriculture vernacular in recent years because they are easy to grow, high yielding, and

Gabriel R. Valle

gvalle@csusm.edu

1 Environmental Studies, California State University San Marcos, 333 S. Twin Oaks Valley Road, San Marcos, CA 92096-0001, USA 
nutrient-dense. He also showed me many other crops this current wave of urban agriculturalists would consider weeds, pests, or are entirely uninterested in growing. Verdolagas (also known as purslane), quelites (also known as lamb's quarters), nopal, popalo (also known as papaloquelite, an herb similar to cilantro), and amaranth greens are equally as nutrient-dense and easy to grow, yet remain on the periphery of desirable herbs and crops to grow for consumption.

Amidst the recent threat of COVID-19, home gardens have surged in popularity as they present both a counter-narrative to the industrial food system and a possible way to achieve food security when many people worldwide are suffering from unemployment and food insecurity. Seed companies, both large and small, are finding it challenging to keep their supplies fully stocked. Folks looking for online garden training by agricultural extension agencies have risen, and local nurseries continually restock only to find their supplies depleted in a matter of days. Victory gardening was a movement that emerged during WWII, where community members transformed vacant lots and backyards into bountiful gardens that provided food, employment, and places of refuge (Lawson 2005). Today, that same idea has re-emerged as COVID victory gardens, and gardens are once again admired for their potential to help families and communities through challenging times.

Coupled with the surge in COVID victory gardens is the idea that any response to COVID19 must capture a "we're all in this together" approach. From the early days of the pandemic, frontline healthcare workers and governments have insisted that the best way to slow the spread of the virus is to detail how we are all connected and vulnerable to it. ${ }^{1}$ This was also the case for companies, celebrities, and the media. "True to form, since the COVID-19 pandemic emerged, brands have been quick to invoke ambiguous yet arguably commodified notions of connectivity, care and community, in the service of capitalism" (Sobande 2020). "We are all in this together" is the narrative that is projected as the global response to COVID-19. It encapsulates a world united across difference through the shared experiences of the pandemic, and only through our shared struggles can we return to "normal."

COVID victory gardens are a unique part of this vision because in the attempt to create an inclusive means to combat the precarity accompanied with the pandemic they construct what Ramirez (2015) refers to as "elusive inclusive" food spaces. In other words, COVID victory gardens do not address the power asymmetries that often reproduce in community settings. By not intentionally and strategically attempting to address the unequal balance of power already present in food production, which includes access to land and the resources to grow food, COVID victory gardens are deeply problematic because they assume a white epistemology already inherent in the food systems (Guthman 2008, 2011; Slocum 2007, 2011). Thus, "acting from a white epistemology perpetuates existing structures of power and privilege within food spaces" (Ramirez 2015, 752). Understanding our collective present means understanding how "race, power, and privilege emerge through community food spaces; they either reify existing inequalities or challenge them" (Ramirez 2015, 752).

In the United States, COVID victory gardens are a new strand in the country's long history of "agrarian myth-making," which "suggests that Americans derive defining moral and political virtues from farming as a way of life" (Singer et al. 2020, 4). In a sense, the agrarian myth is a discourse of authenticity that Americans turn toward in times of moral, economic, political, environmental, or social crisis. Since Thomas Jefferson's time, agrarianism has been

\footnotetext{
${ }^{1}$ Kaiser Permanente's add "Together we can fight the spread of COVID-19" is one example of this and can be found on online at https://www.youtube.com/watch?v=PxdMem74Q1Q\&feature=emb_logo
} 
a means to cultivate citizens rooted in place that would "protect the nation from moral decay by providing a vital counterbalance to the disturbance of urban industrialism" (Singer et al. 2020, 19). Throughout history, Americans have turned toward the agrarian myth in times of precarity to discover and recover the moral and ethical virtues needed to support cultural meanings absent in or distorted by industrialism.

Recent COVID victory gardens have emerged in response to this sort of precarity. COVID19 is now the backdrop from which all other things will develop, and that is potentially very scary because the global changes and cognitive shifts associated with COVID-19 have differential impacts. While COVID victory gardening is a legitimate response for reducing a family's reliance on the global food system, how a particular image of the agrarian myth is celebrated has moral and ethical implications for underrepresented, marginalized, and oppressed communities. The current apolitical framing of COVID victory gardens gives evidence to the blindness of the American population to the history and reality of oppression and how people of color have been responding to it for generations. The "we are all in this together" approach taken by government and health care officials "reflects an intersectional color and class blinding that functions to obscure the structural inequities that befall Black and other marginalized groups, who bear the harshest and most disproportionate brunt of anything negative or calamitous" (Bowleg 2020, 917), which includes COVID-19. The coupling of these approaches further embeds color blindness into the American responses to COVID-19.

The reality is that while many middle-class families now cultivating COVID victory gardens (many of whom have the luxury of working from home during shelter-in-place orders) are clamoring to buy starter plants at nurseries, many low-income and recent immigrant families who make-up a large portion of frontline essential workers assuring our food system continues to function have been growing food in home gardens for generations. Their way of living exists in sharp contrast to the hyper-individualism and hoarding that COVID-19 perpetuates. As Alvaro Huerta explains, "to survive the coronavirus, Americans must learn from Chicanos" (Huerta 2020). Fears about the collapse of organized society reveal a nightmarish reality whereby my survival must come at your expense. COVID-19 exposes a worldview comprised of rational egoists driven by cost-benefit analysis. Yet, the world presented by Huerta presents Latinx peoples as "family-oriented, Mexican descendants in el norte [who] commonly rely (socially, economically, spiritually, etc.) on their family members (immediate and extended) on a regular basis" (Huerta 2020).

Home gardens are nothing new. They are elements of the past in the present. The framing of COVID victory gardens depoliticizes urban agriculture by ignoring its long history in marginalized, oppressed, and displaced communities where it has always been part of a struggle for identity, autonomy, and self- and communal-determination. This blindness overlooks the many lessons that Huerta insists must be learned from oppressed communities to generate greater solidarity across racial lines. Building off Kaplan's (2020) work, I argue that this blindness violates what the author refers to as our "food-related obligations," which are our responsibilities to ourselves, our food, and each other. Silencing how communities of color have historically grown food in pursuit of dignity disregards how home gardens in marginalized and oppressed communities are not merely a reactionary response to crisis but part of a historical legacy whereby marginalized and oppressed people have grown food for generations to create and recreate sustainable ways of living that validate their cultures, knowledges, and ways of being (Penniman 2018; Valdovinos 2017; Valle 2017).

Along with the benefits of growing one's food, COVID victory gardens generate a blindness to the prolonged experiences of precarity in communities of color. The agrarian 
myth surfaces when the American public needs moral and ethical footing, in other words, when they need a sense of place. Yet, the imagined farmer or gardener deriving in this myth is rarely an immigrant, a non-English speaker, Indigenous, a female, or non-white. Understanding our collective present through the lens of the agrarian past as virtuous and as a model of civic life is exclusionary and deeply problematic. The agrarian myth tends to omit the histories of violence and dispossession experienced in communities of color (Penniman 2018), and COVID victory gardening is another instance of this same phenomenon. In instances such as COVID victory gardens, when Americans reach for the agrarian myth to remind them of that "authentic" American experience, by not also acknowledging how the histories of violence and dispossession are also authentic American experiences for non-white peoples, gardening simply reproduces white privilege and the same exclusionary systems of oppression we have inherited. Yet, this does not have to be the case. As explained by Singer et al., "agrarian practices of connection are, in effect, ways of manifesting embodied place and rooted solidarity" (Singer et al. 2020, 211). The moral and ethical implications of foregrounding the history of gardening in marginalized, oppressed, and colonized communities is what may allow us to emerge from this global pandemic with a new awareness of our food and our communities.

This conceptual essay explores gardening as a way of life that fosters resilient communities that continually confront the deepening conditions of uncertainty and inequality that the global response to COVID-19 prolongs. For many Latinx peoples, home gardening is not merely something one can join on a whim, but rather part of a community-oriented subjectivity geared at enabling autonomy and cultural determination, even if momentarily (Valle 2017). Many Latinx home gardeners grow food because they can no longer wait on the state to enforce justice. Similar to the critical environmental justice framework proposed by Pellow (2018), many Latinx urban home gardeners share "perspectives that ask whether we should rely on the state to facilitate social change, or whether there may be other paths that can lead us to those goals" (Pellow 2018, p. 16). This approach to growing food is less about exploring what might exist beyond the state and more about working toward a "different model of state intervention" (Pellow 2018, p. 22-23).

This essay embraces "Latinx environmentalisms" (Wald et al. 2019) as a means to capture the many ways Latinx peoples enact environmentalism as a "differential consciousness" (Sandoval 2000, p. 114) to disrupt binaries and imagine third meanings and spaces into being. As explained by Wald et al., "the term Latinx is thus a placeholder that acknowledges forms of indigenous knowledge and practice that colonization attempted to eradicate" (Wald et al. 2019, p. 23). Home gardens are one of those practices and sources of knowledge that colonization has attempted to destroy, and overlooked by the narrative of COVID victory gardens is a more extensive and more profound history of gardening as a way of life.

\section{Something We've Always Done}

"Tenido un jardín todo mi vida / I’ve had a garden all my life," an urban gardener told me in 2016. "En México, éramos muy pobres, pero siempre teníamos comida suficiente / In Mexico, we were very poor, but we always had enough food." Farming and cooking are central to this woman's identity as a mexicana. She grew up in el campo, or the countryside, and food and agriculture remain central to her life. Growing food is not a novelty but a way of life. She spent her childhood in a rural community in the Mexican state of Jalisco, where her and the surrounding families had home gardens, or huerto familiares as she referred to them. The 
food produced in these gardeners was shared throughout the community and rarely reached the marketplace. It was already de-linked from the global food supply chain. It was food of subsistence, not commodity exchange.

When she migrated to the San Francisco Bay Area in the 1960s, she continued this subversive way of life. She is not alone in her actions, as generations of immigrants from Mexico, Latin America, Africa, Asia, and Europe have used their gardens to maintain a sense of identity and connection to their homeland. Patricia Klindienst explains that for many ethnic Americans, "the garden had become a form of resistance to assimilation" (Klindienst 2006, p. 7). While immigrants have historically used home gardens to resist assimilation, Indigenous communities have continued to cultivate homegardens as a means of cultural determination and survival for generations (Mihesuah 2005). Enrique Salmón insists that gardening for indigenous peoples is a way of life that frames indigenous knowledge systems.

This knowledge is a reflection of a way of being or what may be considered a way of life. This is not so much a lifestyle, which often suggests choice, but just being. It is not a movement that can be joined, but rather a resilient worldview from which the people draw whole thinking approaches to every action and choice related to people and place (Salmón 2012, p. 161).

The legacy of home gardens is deeply rooted in the values and ethics of many land-based peoples whose history of resilience and struggle for autonomy and equality has been discounted by the current narrative of COVID victory gardens.

Nevertheless, this silenced history is written in the landscape. Hondagneu-Sotelo (2014) argues that immigrants shaped Southern California through labor and recreation, and "even when migrants have occupied subordinate social positions and have found themselves excluded from legal citizenship, subjected to racism, and relegated to bad, low-paying jobs, they have actively cultivated plants and gardens" (Hondagneu-Sotelo 2014, p. 4). The author goes further to insist that "gardens can serve as minizones of autonomy, as sites and practices of transcendence and restoration" (Hondagneu-Sotelo 2014, p. 4). Gardens, the author claims, "offer compensation for lost worlds" (Hondagneu-Sotelo 2014, p. 4). Cultivating a garden can bring pleasure, tranquility, and beauty to the lives of those who care for the plants and the landscape. Gardens also hold power because they "articulate future possibilities" (Hondagneu-Sotelo 2014 , p. 4). We have arrived at a moment in time where gardening can unite us across difference by weaving together our many strands of history, not by homogenizing them into one, but by carefully crafting a world where many worlds are possible. This is the learning from each other that Huerta and others imagine.

The problem with the apolitical framing of COVID victory gardens as a response to COVID-19 is not that these gardens can produce food or ease uncertainty. Those are all great things for anyone, but the current way COVID victory gardens are celebrated is another form of "slow violence" enacted by privileged classes on those most vulnerable and reinforces unjust social relations. Rob Nixon argues that slow violence "occurs gradually and out of sight, a violence of delayed destruction that is dispersed across time and space, an attritional violence that is typically not viewed as violence at all," which produces "representational, narrative, and strategic challenges" (Nixon 2011, p. 2). The slow violence enacted by the apolitical approach of COVID victory gardens produces blindness to the current realities and reoccurring histories of oppression and how communities of color have responded to oppression in innovative and restorative ways for generations. 
While food insecurity has reached new heights during the pandemic, COVID victory gardening appears only marginally to be about reducing food insecurity. Websites such as goodhousekeeping.com, forbes.com, organicfarming.com, and theartofleisure.com encourage COVID victory gardening as a means to ease the anxiety brought on by the pandemic. In other words, COVID victory gardening has been embraced by those who fear the industrial food system could fail them (Roa 2020). In contrast, for many marginalized, oppressed, and displaced people for whom the food system has already failed, gardening is not merely a means to ease anxiety but also survival. As a home gardener told me in 2015, "This garden saved my life." I do not contend the COVID victory gardens can not or do not ease food insecurity because under certain circumstances they absolutely can and do. I also am not blind to how COVID victory gardens can create a sense of community, and in uncertain times that is extremely important. However, until COVID victory gardens draw attention to how gardening is an act that eases anxiety for some and a practice of survival for others, they will not bring any lasting transformation or justice to the food system because in its present form it can only reify existing power imbalances.

The language of COVID victory gardens is informed with white privilege. It articulates the white epistemology all too common in the food movement that overlooks how gardening is more than alleviating anxiety about the food system (Reynolds and Cohen 2016). The narrative silences how home gardens have historically helped people maintain a land ethic by keeping alive ways of living, providing a means to share ancestral knowledge, and spaces for gardeners to restore dignity and pursue autonomy. Similar to how Ramirez explains that "black geographies offer an alternate telling of history and a different spatial imaginary of the world" (Ramirez 2015, p. 750), home gardening in marginalized, displaced, and oppressed communities tells a different history of how people resist assimilation and pursue well-being in the face inequality and racism through the simple acts of growing food (Valdovinos 2017; Valle 2017). Silencing the histories of marginalized, oppressed, and displaced peoples under a unified banner of "we're all in this together" does more than erase legacies of conflict. It conceals how marginalized, oppressed, and displaced peoples are not merely passive observes who willingly assimilate into "American" culture, but drivers of history who shape their social, cultural, and physical landscapes by growing food that reminds them of who they are, where they come from, and where they will go.

\section{Cultivating Community-Oriented Subjects}

The blunt racial health disparities that characterize the United States predate COVID-19. This pandemic has only exacerbated the classism and racism embedded within our food system, and these disparities will inevitably widen as it continues to unfold. Most recently, Pirtle explains that "racial capitalism is a fundamental cause of disease in the world and will be a root cause of the racial and socioeconomic inequities in COVID-19 that we will be left to sort out when the dust settles" (Pirtle 2020, p. 504). Racial capitalism, which refers to the ways racialized exploitation and capital accumulation are mutually reaffirming (Robinson 1983), has been referred to as the "fundamental cause of inequalities in health" (Link and Phelan 1995). Pirtle insists that the "racist, capitalist frameworks that sustain the modern world is a fundamental cause of COVID-19 within and across countries" (Pirtle 2020, p. 506). Lessening the blow of COVID-19 in marginalized, oppressed, and displaced communities requires challenging the racist system of capitalism altogether. While COVID-19 may have shaken the very foundation of capitalism, it has not uprooted it, at least not yet. 
Not surprisingly, movements and counter-movements for and against capitalism have created stark divisions across the globe. In many countries, the response to COVID-19 more closely resembles combat than public health (e.g., Hoffmann Pfrimer and Barbosa Jr 2020). This top-down militarized response by governments has only further embedded the ethics of individualism and the neoliberal logic of competition, accumulation, and greed in the daily habits of shopping for food, toilet paper, seeds, starter plants, and even hand sanitizer. This hyper-individual, "me against the world" mentality manifests in the over-consumption by privileged consumers (often those with the ability to work from home) and increases the vulnerability already present in many marginalized, oppressed, and displaced communities who are often essential workers keeping our food system alive (Manderson and Levine 2020). This reality increases the need for innovative solutions beyond state intervention. Neoliberalism teaches the world to respond to a crisis by constructing walls and reverting to isolation (even the CDC's language implies this as 'social distancing' suggests severing our social relations rather than directing our attention on physical distance). In contrast, members of many marginalized, oppressed, and displaced communities respond to a crisis by banding together to overcome walls and barriers (Danovick 2020; Greenway 2020; Nittle 2020a; Sax 2020; Wozniacka 2020).

In Huerta's short but powerful essay, he argues that for society to survive coronavirus and to come out the other side with a more socially just world, we need to learn from Chicanas/os because the worldview for many Latinx peoples is one rooted in community - albeit, often not always by choice but by necessity. Their history of the struggle for equity and autonomy is embedded in their actions for community development. Huerta states, "I want Americans to appreciate and learn from the struggles of the Mexican people in el norte - past and presentduring this crisis. Once we overcome this health crisis — which we will — let's unite and create a society without the haves and have-nots" (Huerta 2020). Huerta refers to how survival in the barrio requires strong social networks and what Del Castillo (2007) calls "social citizenship," or a form of citizenship that is recognized through social interaction rather than a category given to one by the state. It is earned, not granted. In marginalized, oppressed, and displaced communities, social citizenship is fashioned through the relationships one creates with others, and for home gardeners, those relationships are vital because they are opportunities for the exchange of knowledge, resources, and values.

Thomas Lyson (2004) understood this, which is why the values and ethics "civic agriculture" focus on community development and local control, but the depoliticized approach to COVID victory gardens does not. In Latinx communities where gardening is central to a way of life, social citizenship serves to improve food security, exchange and broaden agroecological knowledge and offers pathways to develop food sovereignty (Valle 2020). In a sense, it fulfills our food obligations to ourselves and our communities because it allows people to eat healthy and nourishing foods while treating others with respect and dignity.

While moments of social citizenship are essential for the continuity of a way of life that allows marginalizable, oppressed, and displaced people to sustain themselves, they support sustainable agriculture more generally. Of course, all of this is only possible when growing, sharing, and consuming food generates community-oriented subjects. Kristof recently insisted that 'Latino families... seemed more resilient because of their greater' social capital' — bonds of family, home region or church. Instead of being 'criminals, drug dealers, rapists,' as Donald Trump alleged of Mexican immigrants in 2015, [amid COVID-19] Latino immigrants often seem to be models of civil society" (Kristof 2020). 
At a moment in time when the fear and anxiety of a global pandemic occupies the imagination of most Americans, Latinx communities continue to do the work that many Americans simply will not (Nieves 2020; Sengupta 2020). This is not to disregard the racial capitalism of COVID-19 because the threat of infection is real. According to the CDC, Hispanics and Latinos are 2.6 times more likely to test positive, 4.6 times more likely to be hospitalized, and 1.1 times more likely to die from naval coronavirus. ${ }^{2}$ These bleak findings underscore the structural inequalities embedded in capitalism, which puts certain bodies more at risk than others. These structural inequalities are found in our practices of urban planning, which has created unhealthy environments that have led to high levels of "at-risk" people (i.e., those living with diabetes, obesity, asthma, and other dietary and lifestyle diseases) living in poverty, and in our health care system, which is easier for specific individuals to access than others.

COVID-19 has made the crisis of capitalism more visible, and while many stores are closing because of "stay at home orders," Latino-owned stores have been some of the hardest it. A Sandford study revealed that nearly two-thirds of Latino-owned stores will be out of business if the current "state at home order" stays in effect (Orozco et al. 2020). Perhaps the best way to combat COVID-19 is not merely to "stay at home," but to engage in community building practices that encourage solidarity and trust.

\section{Beyond Victory Gardens}

I have been conducting research with Latinx gardeners for the past decade, and each of them grows food for various reasons. Some grow for pleasure, some for love, some for subsistence, and some to keep traditions alive. Nevertheless, in every instance, they grow to attain at least some level of self-determination and autonomy. The crisis of COVID-19 is now the backdrop for which life now takes place. The question is no longer if the pandemic will reshape our lives, but how will it reshape our lives. Calori and Federici (2020) recently wrote about the European response to COVID-19. The authors argue that when COVID-19 disrupted social life in Milan, Italy, citizens who had already established micro-networks were better situated to withstand crisis. The authors stated that,

Those who managed to face the situation in a better way are the people who previously made individual choices in favour of sustainable lifestyles (rationalization of consumption, reduction of waste, recycling, local purchases, limited intermediation, etc.) and, above all, those who were already part of networks organized for the purchase of food such as, for example, solidarity economy networks, Community Supported Agriculture, consumer cooperatives, local consortia, etc. (Calori and Federici 2020, p. 615).

The authors argue that amidst the global pandemic, acquiring food requires both private and public responses. They insist that "lifestyles are not to be traced only to the sphere of the 'private' or the 'individual', or to be separated or opposed to the public or to the market dimension, but they are part of the structural aspects of our society" (Calori and Federici 2020, 615). The authors allude to the idea that social networks, like those described by Huerta (2020) as prevalent in Latinx communities, are legitimate and reasonable responses to crises. In effect,

\footnotetext{
${ }^{2}$ For more information and to download the full report of the COVID-19 Hospitalization and Death by Race/ Ethnicity from the CDC visit: https://www.cdc.gov/coronavirus/2019-ncov/covid-data/investigations-discovery/ hospitalization-death-by-race-ethnicity.html
} 
social networks create resilient individuals and communities that are better positioned to cope with crisis.

And yet, there always remains the potential to weaponize crisis (see Klein 2007), and COVID-19 is not immune to this. The sense of urgency in which governments have responded to the pandemic is often rooted to maintain "business as usual." We can see this in the way that systemic racism continues to place people of color at greater risk to COVID-19 (Oppel Jr et al. 2020) and how the food system only exacerbates this harsh reality (Alkon et al. 2020; Nittle 2020b). While COVID-19 has intensified the marginalization and oppression experienced in communities of color, it has also encouraged people to think differently about their relationships.

My experience working with marginalized, oppressed, and displaced home gardeners has led me to believe that they carry a garden subjectivity that challenges the one-off society in which we live where risks are created by society and experienced by individuals. Such neoliberal logic has created a society that allows the state to abandon responsibility while placing those most vulnerable at the mercy of the market's inherent unpredictability. The market-based approach to crisis forces division rather than unity and compels the consuming subject to perceive a world full of disposable objects. This is the exact opposite of what is needed in a time like this. On the other hand, home gardens compel people to act relationally with the food, community, and environment. Gardening is not just an act. It is a value system that holds worlds together.

If we are true to our food-obligations, then we have a moral and ethical responsibility to assuring these worlds do not get concealed by COVID victory gardens, but that they become part of the rallying call to transform our food system into something more just and sustainable. As articulated by Arundhati Roy, "the pandemic is a portal," and "we can choose to walk through it, dragging the carcasses of our prejudice and hatred, our avarice, our data banks and dead ideas, our dead rivers and smoky skies behind us. Or we can walk through lightly, with little luggage, ready to imagine another world. And ready to fight for it" (Roy 2020).

We need more home gardeners because I genuinely believe that the more home gardens we have, the more we can disrupt the global food system that has wreaked havoc on our bodies, communities, and environments, but we need to go about enacting gardens in ways that do not engage in the "violence of forgetting" (see Lowe 2006, p. 206). We need systems and institutions that compel us to confront racism and inequality not just because it is morally and ethically the right thing to do, but because "to change everything, we need everyone."3

Marginalized, oppressed, and displaced people have grown food at home for generations and for countless reasons. The apolitical narrative of COVID victory gardens does more than forget this history. It casts these same people as mere bystanders caught up in systems and processes far greater than themselves. Huerta's point is that we must learn from these histories not merely because they tell us how people have survived through centuries of racism and oppression, but because they can inform us of how to overcome centuries of racism and oppression and move us toward a more just future. The apolitical narrative of COVID victory gardens is a neoliberal response to crisis. It proposes that food insecurity is an individual problem resulting from individual people and families lacking the ability to acquire food. This approach suggests the individualized solution of growing one's own food. But the truth of the matter is that food insecurity brought on by COVID-19 is not an individual problem, but a political problem needing collective and systemic solutions.

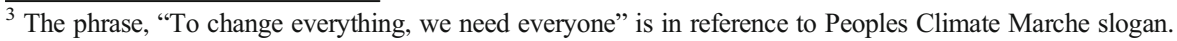




\section{Conclusion}

Immigrants shape the world. As explained by Klindienst, "the immigrant is never simply uprooted or transplanted. The immigrant is not a plant but a gardener - shaping the world, not simply being shaped by it" (Klindienst 2006, p. 76). The recent surge in COVID victory gardens is blinded by this reality, and erasing this history is a form of epistemological violence that disregards the variety of ways that marginalized, oppressed, and displaced peoples continue to shape the food system. This blindness is only the latest example of how the American population is blind to the histories and realities of oppression in communities of color and to their innovative responses to racism and inequity. Our uses of COVID victory gardens must pay homage to the accounts of people who have grown food as a way of life because that history may provide solutions for a more just, collaborative, and sustainable society.

I got into the study of food because I was interested in the relationships between food and the human experience. COVID-19 has inevitably altered that that relationship, and where the food system will go from here has yet to be determined. The future is both incredibly bleak and remarkably hopeful. Home gardens are something that people in all parts of the world have done to remain self-determining, and it is now the time to learn from those individuals and communities. Perhaps our ancestors have already given us the tools to survive this pandemic. Home gardens do far more than produce food; they produce relationships. They allow gardeners to buffer uncertainty while at the same time, making sure that their ways of living continue.

In 2016, a home gardener gave me advice about growing food. He said that the most important thing you could do every day was to greet your garden. "When you greet your garden," he said, "you greet life." He explained how his garden was an extension of himself. It was, in essence, his relationships. It is not only his story, but his way of life. Embedded in his garden is more than the lessons of traditional agroecological knowledge passed down to him from his elders, but the ethics and values he has learned through a lifetime of growing and sharing food.

I think Alvaro Huerta is right when he insists that for our society to survive coronavirus, we need to learn from Chicanos, and we need to look no further than how Latinx home gardeners have cultivated food to maintain a way of living that values our social and ecological relationships. This is not to romanticize a "sense of community" for all Latinx peoples because our experiences and realities are complicated, contradictory, and intersectional. We cannot allow the narrative of COVID victory gardens to be blind to or homogenize the long and complicated history of home gardeners because those complex histories are sources of knowledge that may provide pathways to overcoming this, and perhaps future, pandemics. Learning from those histories will only enlighten us to the nuances of growing food and perhaps provide us more useful tools to reshape our food system into something more just, sustainable, and perhaps even local.

\section{Declarations}

Conflict of Interest On behalf of all authors, the corresponding author states that there is no conflict of interest.

\section{References}

Alkon, Alison H., Sarah Bowen, Yuki Kato, and Rara Lexis Young. 2020. Unequally vulnerable: A food justice approach to racial disparities in COVID-19 cases. Agriculture and Human Values 37: 535-536. https://doi. org/10.1007/s10460-020-10110-z. 
Bowleg, Lisa. 2020. We're not all in this together: On COVID-19, Intersectionality, and structural inequality. American Journal of Public Health 110 (7): 917 https:/ajph.aphapublications.org/doi/abs/10.2105/AJPH. 2020.305766.

Calori, Andrea, and Frencesca Federici. 2020. Coronavirus and beyond: Empowering social self-organization in urban food systems. Agriculture and Human Values. 37: 615-616. https://doi.org/10.1007/s10460-02010111-y.

Danovick, Tove. 2020. Gardening is important, But Seed Saving is Crucial. Civil Eats. https:/civileats.com/ 2020/04/21/gardening-is-important-but-seed-saving-is-crucial/. Accessed 1 Sept 2020.

Del Castillo, Adelaida R. 2007. Illegal status and social citizenship: Thoughts on Mexican immigrants in a Postnational world. In D. A. Segura \& P. Zavella. Women and migration in the U.S.-Mexico borderlands: A reader (pp. 92-105). Durham: Duke University Press.

Greenway, Twilight. 2020. Food as medicine on the Navajo nation. Civil Eats. https://civileats.com/2020/06/04/ food-as-medicine-on-the-navajo-nation/. .

Guthman, Julie H. 2008. Brining good food to others: Investigating the subject of alternative food practice. Cultural Geographies 15: 431-447.

Guthman, Julie H. 2011. "If they only knew": The unbearable whiteness of alternative food. In Cultivating food justice: Race, class and sustainability, ed. Alison Alkon and Julian Agyeman, 221-238. Cambridge: MIT Press.

Hoffmann Pfrimer, Matheus, and Ricardo Barbosa Jr. 2020. Brazil's war on COVID-19: Crisis, not conflictDoctors, not generals. Dialogues Human Geography. 10: 137-140 2043820620924880.

Hondagneu-Sotelo, Pierrette. 2014. Paradise transplanted: Migration and the making of California gardens. Berkeley: University of California Press.

Huerta, Alvaro. 2020. Barrio wisdom: To survive the coronavirus, Americans Must Learn from Chicanos. L.A. Taco https://www.lataco.com/chicanos-coronavirus/. Accessed 5 Apr 2020.

Kaplan, David M. 2020. Food philosophy: An introduction. New York: Columbia University Press.

Klein, Naomi. 2007. The shock doctrine: The rise of disaster capitalism. New York: Macmillan.

Klindienst, Patricia. 2006. The earth knows my name: Food, culture, and sustainability in the gardens of ethnic Americans. Boston: Beacon Press.

Kristof, Nicholas. 2020. Now is time to learn from Hispanic Americans. New York Times. https://www.nytimes. com/2020/06/27/opinion/sunday/hispanic-americans.html. Accessed 1 July 2020.

Lawson, Laura J. 2005. City Bountiful: A century of community gardening. Berkeley: University of California Press.

Link, Bruce G., and Jo Phelan. 1995. Social conditions as fundamental causes of disease. Journal of Health and Social Behavior: 80-94.

Lowe, L. 2006. The intimacies of four continents. In Haunted by empire: Geographies of intimacy in north American history, ed. A.L. Stoler, 191-212. Durham: Duke University Press.

Lyson, Thomas A. 2004. Civic agriculture: Reconnecting farm, food, and community. Medford: Tufts University Press.

Manderson, Lenore, and Susan Levine. 2020. COVID-19, risk, fear, and fall-out. Medical Anthropology 39 (5): 367-370. https://doi.org/10.1080/01459740.2020.1746301.

Mihesuah, Devon Abbott. 2005. Recovering our Ancestors' gardens: Indigenous recipes and guide to diet and fitness. Lincoln: University of Nebraska Press.

Nieves, Evelyn. 2020. 'Essential' but unprotected, farmers live in fear of Covid-10 but keep working. Inside Climate News. https://insideclimatenews.org/news/03042020/covid-farmworkers-california-climate-changeagriculture. Accessed 20 Apr 2020.

Nittle, Nadra. 2020a. How black communities are bridging the food access gap. Civil Eats. https:/civileats.com/ 2020/07/07/how-black-communities-are-bridging-the-food-access-gap/. Accessed 20 Aug 2020.

Nittle, Nadra. 2020b. People of color are at greater risk of COVID-19. System Racism in the Food System Plays a Role. Civil Eats. https://civileats.com/2020/05/05/people-of-color-are-at-greater-risk-of-covid-19systemic-racism-in-the-food-system-plays-a-role/. Accessed 20 Aug 2020.

Nixon, Rob. 2011. Slow violence and the environmentalism of the poor. New Haven: Harvard University Press.

Oppel Jr., Richard A., Robert Gebeloff, K.K. Rebecca Lai, Will Wright, and Mitch Smith. 2020. The fullest look yet at the racial inequality of coronavirus. New York Times. https://www.nytimes.com/interactive/2020/07/ 05/us/coronavirus-latinos-african-americans-cdc-data.html. Accessed 1 Sept 2020.

Orozco, Marlene, Inara Sunan Tareque, Paul Oyer, and Jerry I. Porras. 2020. The ongoing impact of COVID-19 on Latino-owned businesses. A research brief prepared by Stanford Latino Entrepreneurship Initiative. https://www.gsb.stanford.edu/faculty-research/publications/ongoing-impact-covid-19-latino-ownedbusinesses. Accessed 1 Sept 2020.

Pellow, David N. 2018. What is critical environmental justice? Medford: Polity. 
Penniman, Leah. 2018. Farming while black: Soul fire farm's practical guide to liberation on the land. White River Junction: Chelsea Green Publishing.

Pirtle, Whitney N. Laster. 2020. Racial capitalism: A fundamental cause of novel coronavirus (COVID-19) pandemic inequalities in the United States. Health Education \& Behavior 47 (4): 504-508.

Ramirez, Margaret Marietta. 2015. The elusive inclusive: Black food geographies and Racialized food spaces. Antipod. 47 (3): 748-769.

Reynolds, Kristin, and Nevin Cohen. 2016. Beyond the kale: Urban agriculture and social justice activism in New York City. Athens: University of Georgia Press.

Roa, Tajal. 2020. Food supply anxiety brings Back victory gardens. The New York times. https://www.nytimes. com/2020/03/25/dining/victory-gardens-coronavirus.html. Accessed 26 Mar 2021.

Robinson, Cedric J. 1983. Black Marxism: The making of the black radical tradition. Chapel Hill: University of North Carolina Press.

Roy, Arundhati. 2020. The pandemic is a portal. The Financial Times. https:/www.ft.com/content/10d8f5e874eb-11 ea-95fe-fcd274e920ca. Accessed 26 Feb 2021.

Salmón, Enrique. 2012. Eating the landscape: American Indian stories of food, identity, and resilience. Tuscan: University of Arizona Press.

Sandoval, Chela. 2000. Methodology of the oppressed. Minneapolis: University of Minnesota Press.

Sax, Sarah. 2020. A Vietnamese Farmers' cooperative in New Orleans offers a lesson in resilience. Civil Eats. https:/civileats.com/2020/05/01/a-vietnamese-farmers-cooperative-in-new-orleans-offers-a-lesson-inresilience/. Accessed 1 July 2020.

Sengupta, Somini. 2020. Heat, smoke and Covid are battering the workers who feed America. New York Times. https://www.nytimes.com/2020/08/25/climate/california-farm-workers-climate-change.html. Accessed 5 Sept 2020.

Singer, Ross, Stephanie Houston Grey, and Jeff Motter. 2020. Rooted resistance: Agrarian myth in modern America. Fayetteville: University of Arkansas Press.

Slocum, Rachel. 2007. Whiteness, space, and alternative food practice. Geoforum 38 (3): 520-533.

Slocum, Rachel. 2011. Race in the stud of food. Progress in Human Geography. 35 (3): 303-327.

Sobande, Francesca. 2020. 'We'Re All in This Together': Commodified Notions of Connection, Care and Community in Brand Responses to COVID-19. European Journal of Cultural Studies 23 (6): 1033-37. https://doi.org/10.1177/1367549420932294.

Valdovinos, María Guillen. 2017. Travels of a diaspora community: From La Sierra Madre y Tierra Caliente to the Pacific northwest. In Mexican-origin foods, Foodways, and social movements: A Decolonial reader, ed. D.G. Peña, L. Calvo, P. McFarland, and G.R. Valle, 169-187. Fayetteville: University of Arkansas Press.

Valle, Gabriel R. 2017. Food values: Urban kitchen gardens and working-class subjectivity. In Mexican-origin foods, Foodways, and social movements: Decolonial perspectives, ed. D.G. Peña, L. Calvo, P. McFarland, and G.R. Valle, 41-62. Fayetteville: University of Arkansas Press.

Valle, Gabriel R. 2020. Learning to be human again: Being and becoming in the home garden commons. Environment and Planning E: Nature and Space. https://doi.org/10.1177/2514848620961943.

Wald, Sara D., David J. Vázquez, Priscilla Solis Ybarra, and Sarah Jaquette Ray. 2019. Introduction: Why Latinx environmentalism? In Latinx environmentalisms: Place, justice, and the Decolonial, ed. S.D. Wald, D.J. Vázquez, and P.S. Ybarra, 1-31. Philadelphia: Temple University Press.

Wozniacka, Gosia. 2020. The doctor-botanist couple healing a Community in the Rural South. Civil Eats https:// civileats.com/2020/07/14/the-doctor-botanist-couple-healing-a-community-in-the-rural-south/. Accessed 1 June 2020.

Publisher's Note Springer Nature remains neutral with regard to jurisdictional claims in published maps and institutional affiliations. 